\title{
11. Witchcraft, Torture and HIV
}

\author{
NICOLE HALEY
}

After questioning us further, they dragged me over to the Casuarina trees. They tied ropes around my hands and legs and tied me to one of the trees. I protested, 'I am not a witch, I have done nothing'. They then dragged my mother to the other side and tied her between two Casuarina trees as well. My mother said, 'I don't know what you have planned for me, but let me pray first'. While she was praying they were heating an iron bar. It was not just any piece of iron, they had fashioned it such that it was like a fishing spear with two hooks on the end. She prayed and just as soon as she said 'Amen' they got that iron bar and thrust it into her vagina. They cooked her vagina and ripped out her uterus. The smell was unbelievable. ....I couldn't do anything to help my mother as they had tied me up good and proper... That night it rained constantly. They left us there, just the two of us in the rain. While it was raining MP [a local pastor] came. He touched my body all over and said 'I was feeling sorry for you, so I've come to loosen the ropes' .... He continued touching me all over then said, 'Seeing you tied like this has aroused me. I want to fuck you'. He touched me and did terrible things to me. He then threatened me and told me not to tell anyone. That happened in the middle of the night. In the morning when the sun came up I saw clearly what they had done to my mother. Her legs were burnt and swollen, her vagina was cooked and buggered up completely, and she had lost plenty of blood. I knew then she was as good as dead... ${ }^{1}$

Accused Woman 2, 23 June 2004, Lake Kopiago, Southern Highlands Province

\footnotetext{
1 This quote is drawn from a much larger unpublished account concerning a witch trial that occurred at Lake Kopiago in December 2003. The young woman in her mid-twenties was held and tortured over a 13-day period, along with five other women including her mother, who died as a result of the injuries she sustained. Although the women involved wish their stories to be told I have protected their identities.
} 


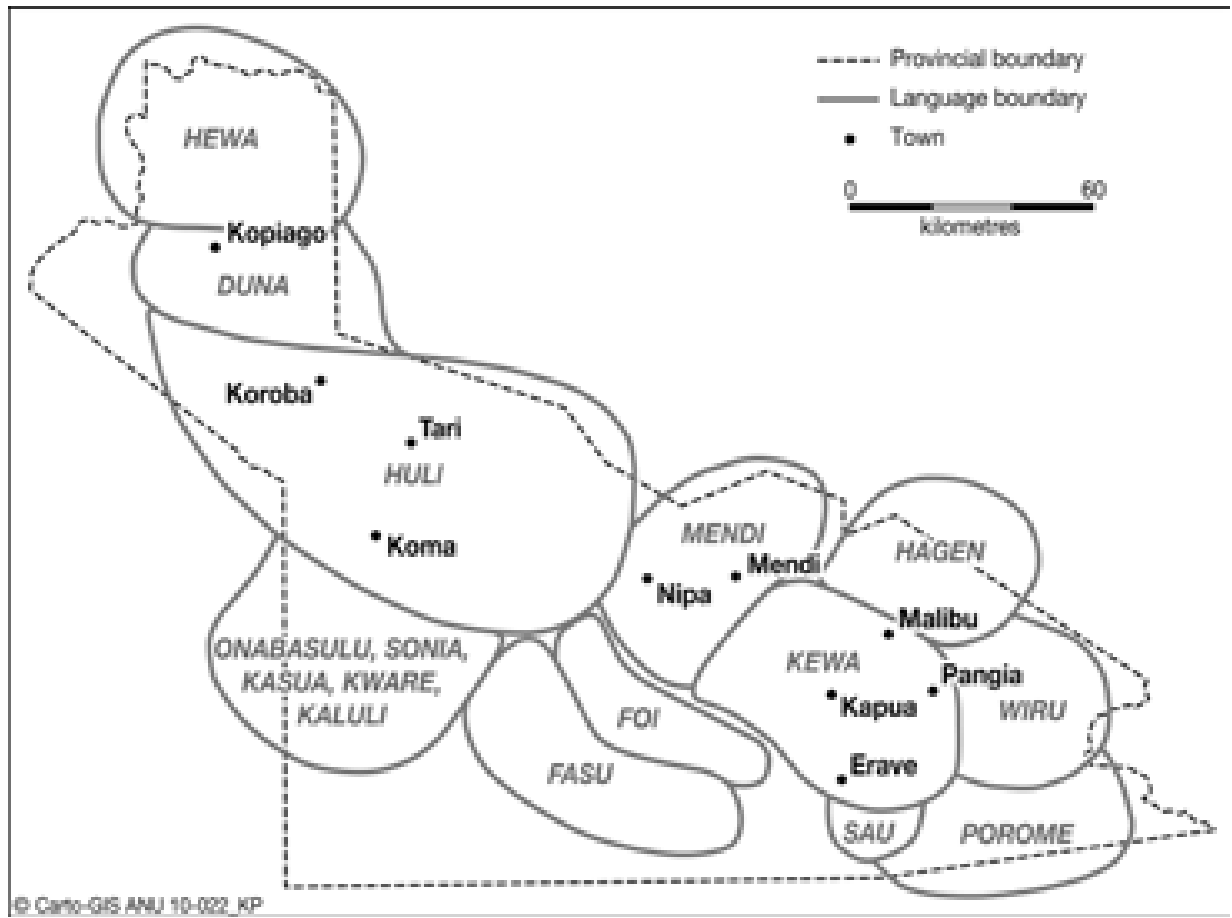

\section{Map 3: Southern Highlands Province.}

By Karina Pelling, Coombs Cartography, College of Asia and the Pacific, The Australian National University, Canberra, Australia.

\section{Introduction}

Accusations of witchcraft and sorcery, resulting in torture and sometimes death, appear to be increasing throughout Papua New Guinea and have prompted the current review of the nation's sorcery laws (Anon. 2009; Springler 2005, 68). Dozens of stories appearing in the Post Courier and National newspapers and carried by international news services give the impression that witch trials and killings are prevalent, especially in the Highlands, and on the rise. ${ }^{2}$ At Goroka General Hospital in the Eastern Highlands Province, staff report growing numbers of patients with trauma from witch-torture. They also report that people are increasingly requesting post-mortem examinations in the hope of demonstrating sorcery or witchcraft as a cause of death (Kubu et al. 2004, 11). Dokup (2004) found that surgical wards in the Highlands were admitting more than 10 torture victims each week. These admissions do not, however, reflect the

2 Torture headlines from around the time of the Kopiago witch trials discussed here have included Anon. 2003a; Anon. 2003b; Anon. 2004a; Anon. 2004b; Anon. 2004c; Anon. 2004d; Anon. 2004e. More recent media coverage includes Anon. 2007; Anon. 2008; Anon. 2009; Muri 2009. 
true extent of the problem. Dr Joe Aina of Kundiawa General Hospital has stated that only a fraction of those tortured and killed as witches come to the attention of medical services. ${ }^{3}$ Perhaps even fewer come to the attention of police. For the most part these injuries and deaths go unreported.

Several observers, including the former Minister for Police and Internal Security, Bire Kimisopa, have directly linked this apparent increase in witchcraft accusations with PNG's growing HIV epidemic (Gerawa and Rheeney 2004). In many reported cases of witch-killing - such as the incineration of a young Mt Hagen woman in early 2009-AIDS has been explicitly implicated (Muri 2009; see also Anon. 2007). Classical analyses of witchcraft in fact correlate the efflorescence of witchcraft beliefs, in particular places at particular times, with periods of illness, misfortune and uncertainty (e.g. Marwick 1965), and have explained witchcraft and sorcery in terms of anxieties born of radical social change, suggesting that accusations arise when communities experience dramatic upheavals and conflicts precipitated by epidemics, labour migration and political insecurity. Certainly two of the most comprehensive studies of witchcraft/sorcery ${ }^{4}$ in PNG, namely Lindenbaum's (1979) study of Kuru sorcery and Reibe's (1987) study of Kalam witchcraft, argued that particular PNG communities have used witchcraft and sorcery to explain sudden changes to mortality rates. Lindenbaum's study also showed that as the incidence of illness amongst the Kuru declined, so did sorcery accusations.

I too will argue that sorcery accusations and the HIV epidemic are linked, although on numerous occasions the torture or killing of an alleged witch is unrelated to any perceived or actual death from AIDS (cf. Durkheim 1952 on Suicide). I draw on material from Lake Kopiago, in Southern Highlands Province, where I have conducted research over the past 16 years. There AIDS deaths are being attributed to the agency of witches, while illness and death associated with HIV have heightened anxieties about witchcraft more generally. I shall provide an account of the Kopiago witch trials that occurred in the 18 months from December 2003 and ask why it is that AIDS deaths lend themselves to witchcraft accusations. I will not seek to explain witchcraft per se and, for the purpose of discussion, I will accept the view that witchcraft accusations have increased, without tackling the vexed question of whether the rise of

\footnotetext{
3 These claims were made at a workshop entitled Sanguma in Paradise: Sorcery and Witchcraft in the Highlands of Papua New Guinea. The workshop organised by the Melanesian Institute was held at Goroka from 7-11 September 2004. At the workshop Dr Aina reported that he himself had treated 44 people tortured as witches between 1996 and 2004. See Zocca 2009.

4 Following the work of Evans-Pritchard (1937) among the Azande, anthropologists have tended to distinguish between sorcery and witchcraft on the basis that witches are seemingly possessed of an innate and unconscious propensity to harm others, whereas sorcery involves the conscious and deliberate manipulation of objects and/or spells to achieve a desired outcome. This broad distinction is applied herein, however I note that witchcraft and sorcery are both subsumed under the term sorcery in the PNG Sorcery Act 1976, and that they tend to be used interchangeably in PNG media reports.
} 
witchcraft accusations is actual or merely perceived. ${ }^{5}$ Rather, I will explore how AIDS deaths contribute to witchcraft accusations in the Lake Kopiago area by attempting to elucidate the cultural logics and other factors which shape Duna people's experiences of HIV and AIDS. Finally, I will consider the implications for law and order in PNG.

\section{Lake Kopiago-The Setting}

Some 30,000 Duna speakers, alongside 5000 Hewa and 250 Bogoi, live in the Lake Kopiago sub-district, an area of about $3800 \mathrm{~km}^{2}$ in the far northwestern corner of Southern Highlands Province (SHP). Despite the SHP's lucrative natural resources, it is arguably PNG's worst-performing province (see Haley and May 2007). Service delivery has ground to a halt, human development indicators are among PNG's lowest (McKay, Lepani and Wagner 1999) and the province is riven by armed violence. A recent survey sponsored by the United Nations Development Programme (UNDP) and undertaken in collaboration with the Geneva-based Small Arms Survey found that the western end of the Southern Highlands is disproportionately affected by armed violence and its victimisation rates are amongst the highest reported anywhere in the world (Haley 2005, 25-26; see also Haley and Muggah 2006). Specifically 65 percent of households surveyed in the Kopiago sub-district reported victimisation, with respect to armed violence, in the six months to May 2005 (Haley 2008a).

Compounding this, demand for firearms in the province is robust and there are no police and no village court magistrates. In the absence of such formal dispute resolution mechanisms, compensation demands (now exacted at gunpoint) have escalated to the point of crippling livelihoods and fuelling renewed cycles of retribution and violence. The situation in the health and education sectors is equally disconcerting. Most public servants have absconded. Aid posts have closed down. Medicines are in short supply. Vaccination and other health programs, including disease surveillance, have ceased. Schools have shut. Road

\footnotetext{
5 Although anecdotal evidence suggests a recent upsurge in witchcraft activity, it should be noted that researchers in the 1970s and 1980s felt they too were witnessing 'a recent increase in sorcery and witchcraft beliefs in Papua New Guinea' (Lindenbaum 1981:119). In the 1980s, for instance, two edited collections concerning witchcraft and sorcery in PNG were published (Zelenietz and Lindenbaum 1981; Stephen 1987). The papers contained within both collections sought to document the emergence of new practices and the efflorescence of existing ones. Further research concerning contemporary witch hunts, combined with detailed historical and empirical accounts of witchcraft placed within local contexts, is therefore needed before we can say with any certainty whether witch killings are on the rise. Ethnographies from across the Highlands and the Highlands fringe make evident that witch trials and killings were certainly a feature of the recent past in many areas (Reay 1987; Glasse 1965; Kelly 1977; Maracek 1979; Poole 1981; Knauft 1985); that torture was often used to elicit confessions from suspected witches prior to execution (Poole 1981; Reay 1987:97-98); and that killings took place reasonably frequently. Steadman (1971), for instance, recorded 42 witch killings amongst the 460-odd Central Hewa in the period 1959-1969 alone, while Poole (1981:59) reported that the Bimin-Kuskusmin, who at the time of his fieldwork (1971- 1973) numbered around 1000, could vividly recall 73 witch killings. He further noted (1981:59) that 'almost every adult' could 'recall having witnessed the public spectacle of the tortured confession and hideous execution, of a witch'.
} 
closures, unchecked conflicts in the Koroba area, and the rising cost of air travel also mean that people can no longer access Tari Hospital. The cessation of passenger flights between Kopiago and Mendi (the provincial headquarters) prevent travel to the main provincial hospital too, so health services of any kind are very hard for people at Kopiago to reach. In addition, the cash economy has contracted, giving rise to an increase in transactional sex and the proliferation of polygamous, often short-lived marriages and unions through which Duna seek to access employment incomes and the benefits of resource development.

Men and women alike recognise that these changing sexual and marriage practices are a key source of violence in their communities. Household surveys and focus groups conducted with men and women separately in May 2005, as part of the UNDP sponsored Armed Violence Assessment (Haley 2005), revealed that family or domestic violence (imanoni wei, literally woman and husband fight) is the primary contributor to insecurity in the Lake Kopiago area. It was also found that in the six months to May 2005 domestic violence affected one-third of the 103 households surveyed and that 70 percent of the domestic violence reported had involved the use of a weapon. ${ }^{6}$ Both men and women agreed that domestic or family violence arises, in one way or another, from tensions due to promiscuity, transactional sex, polygamy and marital infidelities (see also Haley 2008a). Against this backdrop people in the Lake Kopiago subdistrict are experiencing the HIV epidemic.

\section{HIV and AIDS at Kopiago}

Although the Catholic Church has recently begun voluntary testing and counselling at Lake Kopiago, very few people know, even if they want to, their HIV status or have ever been tested. Accordingly there are few confirmed AIDS deaths at Kopiago and the overall prevalence of HIV infection remains unknown. Yet personal observation and anecdotal evidence suggests that growing numbers of men, women and children are living with HIV and dying from AIDS. Men are returning home from larger urban centres such as Moresby, Lae and Mt Hagen to die and many deaths 'in the village' appear to be AIDS-related. The officer-in-charge of the Lake Kopiago Health Centre reports a dramatic rise in tuberculosis since 2002 (Ekara Andape, personal communication 2004), which likewise suggests an increase in the prevalence of HIV.

In nearby Tari District, testing at Tari Hospital has confirmed a dramatic increase in the prevalence of TB and rising HIV. In 2005 Frank Kasahya, the pathologist

6 Further analysis of the Lake Kopiago data revealed that of the domestic violence cases in which a weapon was used, a bush knife or axe was used in all but one case, while firearms were used as well in 57 percent of the reported domestic violence events (Haley 2008a, 228). 
at Tari Hospital, found a '2-3 percent HIV prevalence rate amongst those tested' with 'at least two new confirmed HIV cases each week' but pointed out that 'the majority of people are afraid to come forward for testing' and that 'plenty of people are dying without being tested' (Kasahya, personal communication May 2005). Figures released by the SHP provincial AIDS office reveal at least a five-fold increase in new HIV cases between 2003 and the first quarter of 2005,7 while testing in Tari in 2006 was reported to show an HIV prevalence of 40 percent among people aged from 15 to their early 40s (Anon. 2006; cf. Wardlow 2008, 190-191).

Because health and education services are barely functioning and literacy rates are amongst the lowest in the country, people at Lake Kopiago are experiencing the epidemic with very limited public education about HIV and AIDS. The few national awareness messages in the electronic and printed media that have penetrated only bewilder the Duna, who are unsure about the nature of the virus, its modes of transmission and illnesses which accompany it (see also Eves 2003, 253). Even in cases where a person's HIV status has been confirmed, AIDS deaths, like all deaths, are primarily interpreted and understood with reference to local conceptions of illness and disease.

At Lake Kopiago, the HIV epidemic is unfolding within a cosmology characterised by entropy and a concept of the 'ground finishing' (rindi itaraiya). Duna hold that their world is bound up in a process of loss, with the fertile substance that sustains the universe tending, as Duna myths reveal, to dissipate. Declining fertility manifests in environmental degradation and in social and moral disarray. As fertility is morally constituted (cf. Ballard 1998; 2000), ongoing fertility must be negotiated through appropriate moral behaviour and proper social intercourse (Haley 2002). These underlying beliefs inform the way Duna interpret and understand environmental and social changes, including the manifestations of HIV (see also Haley 2008b).

Duna disease aetiology clearly links illness and disease with the erosion of traditional moral codes, such that deportment and physical wellbeing are seen to reflect the state of the world more generally. Accordingly Duna view HIVassociated illness and death as symptomatic of the 'ground finishing'. They talk about AIDS deaths alongside observations about corruption, the proliferation of small arms, incestuous marriages, gambling, the non-payment of bride-price, and the heightened immorality and promiscuous sexuality of youth-all of which are viewed as evidencing the social and moral decline of their world (cf. Eves 2003).

7 Figures released by the SHP provincial AIDS office reveal that there were 44 new cases of HIV reported in 2003, 66 new cases in 2004 and 56 new cases in the first 3 months of 2005. The 2003 and 2004 figures incorporate those from Tari, Mendi and Ialibu Hospitals, whereas the 2005 figures record only the new cases from Tari and Mendi (Pacific Magazine, 17 June 2005). 


\section{AIDS and Witchcraft}

From a Duna perspective, the approaching apocalypse is also being hastened by an apparent upsurge in witchcraft activity. Duna hold that witches (suwake) threaten the flow of fertile substance. They devour it through the consumption of people's bodies and through their insatiable sexual appetites. Witches transgress social and moral boundaries. They are seen as mobile, greedy for food and sexually promiscuous (see Stürzenhofecker 1998, 158-183). Specifically they are said to consume a victim from the inside out, thereby draining them of their fertile substance.

Only those deaths that are sudden or seemingly unusual are attributed to malign causes such as witchcraft (cf. Yamba 1997, 219). For instance, deaths among the very young or the very old seldom result in accusation - they tend not to be considered unusual. Typically only those deaths that run counter to people's experiences - deaths among people of reproductive age, in the prime of their lives - are considered unusual. Duna assert that there have been many unusual deaths in recent times. They are cognisant of the small but steady stream of young men returning home from urban centres to die, and of the growing numbers of people succumbing to chronic respiratory problems.

Hence AIDS produces the kinds of death that lend themselves to witchcraft accusations. The spate of witch trials from December 2003 was triggered by several 'unusual' deaths in the Lake Kopiago area. ${ }^{8}$ In these trials, three women were killed and nine others sustained horrific injuries. In the first trial, which occurred at Hirane in December 2003, six women were held captive and repeatedly tortured over a fortnight. These women, including the young woman to whom the opening quote is attributed, were blamed for a series of 'unusual' deaths including that of a young man who most likely died of HIVrelated tuberculosis in early 2003. The accused women were beaten, stabbed, cut with bush knives and burnt with reinforcing iron. Two of the women were sexually assaulted and one, the mother described at the outset of this chapter, had her uterus ripped out with a hot iron hook. That woman died as a result.

At the time this trouble came up two boys came to my house... They took me to the men's house. When I got there I saw that they had cooked my sister and that other woman. I saw this and I was terrified. They ordered me to go and sit down with my baby. They said, 'Sit there and don't move, we haven't finished with these two yet'. With that they got some wire and tied my hands and legs. They tied me to a Casuarina

8 Research elsewhere has also shown that AIDS deaths were readily attributed to witchcraft as the HIV/ AIDS epidemic took hold in Zambia (Yamba 1997), South Africa (Ashforth 2002; Stadler 2003) and Haiti (Farmer 1990; 1992). 
tree. While I was there, with my baby, they heated that wire. Then they burnt my breasts, my thighs, my backside. They burnt me all over.... The boys that cooked me were my husband's sons - the sons of his first wife. They blamed me for their brother's death.... The marks on my body bear witness to the things they did.... My body is completely wrecked...

Accused Woman 3, 26 June 2004.

In an unrelated trial two months later, two women (a mother and daughter) were killed at Horaile; in June 2004, four women were tortured as witches at Hagini; and in July 2005 a young man was accused and tortured at Kaguane. None of these incidents of torture were formally investigated and the perpetrators are unlikely ever be punished as there are no police or magistrates in the Kopiago sub-district.

In the Kaguane case, the accused was a young man rumoured to be practising a new form of witchcraft believed to have entered Kopiago from the Oksapmin area to the west in 2004. This new form of witchcraft, known locally as kao suwake 'white witchcraft', is thought to only harm young sexually active men. Its name reflects its alleged introduction by a white man, who is reputed to have trained and to command a band of local practitioners. These practitioners are supposed to drain their victims' blood and remove their internal organs for sale in Australia (cf. Englund and Leach 2000, 230).

Anxieties about 'unusual' deaths at Lake Kopiago are being played out in dreams which are publicly aired and often interpreted in terms of witchcraft:

I told you about that boy MW who died on Sunday.... Before he died HK had a dream. He saw a big cassowary behind MW's house. Another cassowary came and met it. ${ }^{9} \mathrm{JK}$ also had a dream. In his dream he saw a long drain. A line of young fruit pandanus was planted beside the drain. The first tree had fruit that was ready to be harvested. That man, the one they have accused, came and picked the fruit.... The people are now saying that dream is proof that $M$ was killed by witchcraft. M's death has proven that this kind of witchcraft is already here... The young fruit pandanus in JK's dream are the young guys around here. In the dream only the first died, but they were lined up along the drainone by one they will be harvested. They are truly worried this 'white witchcraft' will finish them all.

Richard Alo, 24 June 2004.

9 In myths and dreams witches are often paired and appear in the first instance in the singular and in the form of cassowaries. 
The role of AIDS as a contributor to deaths and as a stimulant of witchcraft accusations is not, however, widely perceived among the people of Kopiago themselves. In fact, those who seek to attribute local deaths to the HIV epidemic are often ridiculed.

About those deaths, they keep saying 'kao suwake, kao suwake' ['white magic'], but I'm sure the thing that's killing the young guys around here is in fact this sikAIDS we have heard about. I told the people at Kaguane about that and told the people at the market today, but they didn't want to listen. They laughed at me and said, 'You are wrong. It's witchcraft we have the proof-it's in the dreams and on the skin.'

Richard Alo 24 June 2004.

For people at Kopiago, witchcraft explains the deaths of young and middle-aged men who are usually considered strong, healthy and resilient to disease. In the context of AIDS, the witchcraft paradigm provides a readily accepted 'theory of causation' (Stadler 2003, 364).

While the burgeoning HIV epidemic can only fuel witch-killing at Kopiago, it does not, as I suggested at the outset, directly cause each witchcraft accusation or each witch-killing incident. On the contrary, the circumstances surrounding each case, their nature and the ad hoc explanations that emerge after the fact, remain much the same as they always have. This means it is typically women, especially those who are seen by men to have rejected their customary obligations or to have failed to conform to local gender and sexual stereotypes, who are accused. Of the six women tortured as witches at Kopiago in December 2003, three were widowed, one was divorced, and one was living apart from her husband. They were all living independently of their former in-laws, and were therefore viewed by many, including their in-laws, as having failed to fulfil their customary obligations.

For instance, one of the accused and tortured was a young widow, whose husband had died of cerebral malaria in 2000. Soon after her husband's death she had been accused of killing him using witchcraft. She and her relatives had denied the accusations, but had paid compensation to her dead husband's kin 'to solve the trouble'. In the course of the December 2003 witch trial she was targeted and tortured for failing to 'sit down good' with her in-laws and for her intemperate sexuality - that is for having a child with another man. She was tortured by her dead husband's older brother:

...the boys came. They dragged me to the men's house... They dragged me back to the place where they had cooked [Accused Woman 1]... When we came up to that place I saw that they were already heating the wire.... They got rope and tied me and my small baby to a Casuarina 
tree. M2 said, 'Tie that bastard child to the tree with her!' After they had tied us both, he grabbed a bush knife and cut the baby's neck. I screamed, 'Don't cut my baby! If you want to cut me then go ahead cut me. Don't kill my baby'. The baby was crying. He pissed everywhere. With that M3 came and grabbed the baby. I said, 'If you are going to kill my baby then kill us both. Kill us both together' ... With that M4 came and grabbed my baby, he carried him off into the bush and left him there. I didn't know what they had done to him. They carried him away, then tied my legs and hands. They tied me to a Casuarina. Then M5 came and held a bush knife to my neck... While he did that M3 [her brother-in-law] was heating the wire in the fire. When it was red hot he came and shot me right here [just above her left buttock]. The wire went inside me. It went all the way down my leg and came out here [just above her knee]. It was hard for him to get it out again. My body bears the marks of this. This wire was no ordinary wire. They had sharpened it and fashioned a hook, two hooks, at the end. When it was hot really hot they shot it through my leg... Because of the hooks it was hard to remove.... I don't remember how they got it out. I passed out. When I woke they had removed it already... I saw that plenty of flesh and muscle had come out too....

Accused Woman 5, 26 June 2005.

The accused women were also held to have transgressed other gender codes. Indeed throughout their interrogation they were accused of behaving like men and of owning army uniforms, six-pocket trousers and high powered weaponsthe accoutrements of contemporary masculinity in PNG (see Macintyre 2008).

Although they were held, questioned and tortured at the same time, the six women involved in the Hirane witch trial were tortured by different groups of men and subjected to accusations that differed in their particulars. For instance, AW5's mother, a widow in her late fifties, was accused of being a witch after publicly refusing the sexual advances of an old man who later became sick. Unlike her daughter she was tortured by the old man's sons, who saw fit to punish her insolence by burning her, stripping her naked and sexually assaulting her while she was tied to a Casuarina tree outside their father's men's house:

They dragged me out from my house. They dragged me to the men's house. On the way they booted me. When we got to the men's house they hit me.... One of the boys got a bush knife and cut me.... Then they cooked me. They heated that wire till it was red hot and then cooked my thighs. They tied my hands and legs and told me not to move. Once they had tied me then they cooked me.... After doing that two of the boys, 
tore my dress from me. I was completely naked. The boys then came touched my body all over. I couldn't do anything. I was still tied up. I couldn't do anything. I thought they were going to kill me....

Accused Woman 4, 26 June 2004.

The differences in the particulars of the accusations was underlined by the fact that it was possible for a young male torturer to assume contrasting roles in relation to the different accused women. For instance AW5's principal assailant (her brother-in-law) intervened to stop AW2 (his clan sister) from being burnt when it became evident that her attackers intended to burn her as they had her mother.

\section{Law, Order and Governance Failure}

Whilst it is not altogether surprising that AIDS deaths are now being attributed to the agency of witches, in that AIDS produces deaths of young, sexually active adults which are specifically the kind that attract witchcraft accusations, these Kopiago witch trials, involving prolonged pubic torture that did not cease upon confession, differ markedly from the traditional interrogation of witches. Formerly, accused witches were not ordinarily tortured, punished or killed. ${ }^{10}$ Instead, they were publicly interrogated and urged to confess their misdeeds. The act of confession was thought to be disempowering, and they were then ordered to pay compensation. Only in the case of repeat offences were witches killed, and then by their own kin. Contemporary witch trials at Kopiago seem to be explicitly about punishment and retribution, rather than public confession. As such they have more in common with the way sexual impropriety was dealt with in the past. Traditional punishments for promiscuity and adultery included whipping the woman's genitals with barbed vines or branches, or lashing her to an ant's nest so her genitals would be bitten by ants. ${ }^{11}$

Another key difference is that the interrogation and punishment is being carried out not by community leaders, nor by the women's own kin, but by young men with guns, who would otherwise have very little standing in the community.

\footnotetext{
10 Whilst it was the case that Duna witches were not typically tortured, limited duress was sometimes used to extract a confession. Generally this involved having small slithers of bamboo inserted under their finger nails.

11 I am not aware of any cases in which the woman's genitals were actually burnt, and in fact Duna leaders assert that this did not happen in the past. That said it did happen in other areas. For instance Wagner (1972, 37) describes a Daribi form of punishment known as fire-genitals which was used on women who were found 'guilty of offences connected with intemperate sexual relations'. In it the woman was 'staked out on the ground, and a fire built at her genitals until they are no goodanymore'.
} 
Civic Insecurity

The boys who did these things, they came up like soldiers. Brandishing their guns they said to the leaders and to our relatives, 'No one can come inside the fence. We are going to teach these women a lesson. Do not come inside our territory'.

Accused Woman 4, 26 June 2004.

This has given rise to a great deal of community discord and division. Community leaders at Kopiago publicly decry the actions of these young men who have taken it upon themselves to seek out and punish suspected witches, but lament that they are powerless to intervene given the proliferation of marijuana and small arms.

There is no longer any law and order here. The young guys don't listen to the leaders. Instead they come with guns and threatening words. They smoke marijuana and take matters in their own hands. They are self-promoted leaders. They come with their guns. They threaten us, demand the leaders keep quiet and chase us away. They use their guns to threaten, to demand large compensation, to make their own laws. They say 'witch, witch' and cook the women they accuse. We reject what they are doing but they don't listen to us.

Sane Noma, 12 May 2005.

Kopiago's community leaders are firmly of the view that problems stem directly from service delivery failure and want the government to address them.

In my entire life I have not seen anything like this witch trouble before... Suppose we suspected a woman of being a witch, we would question her and order her to kill a pig. We never touched their bodies or spoiled them like that before. This practice of burning them, there's no law or custom to that effect around here.... That is the first time this has come up here. All this wouldn't have happened if there was law and order, proper medicines and proper health services here.

Jim Siape, 26 June 2004.

Kopiago is not like other districts. We don't have the services they have in other areas. We are without roads, schools and health services. This witch trouble came up here because we don't have police, magistrates or DPI officers [agricultural extension officers]. If we had police they could have investigated and charged those women and if we had DPI officers all these young guys would be busy with agriculture and making business. Instead they have nothing to do, so they grow marijuana and search for guns. We leaders reject what they are doing, but they don't listen to us or respect us. Instead they taunt us and say, 'When are you going 
to bring police and jail us?' We want a District Administrator, proper magistrate, police, village courts and good communication. Currently we have none of these things and that is why these problems came up.

David Lundape, 23 June 2004.

Undoubtedly governance failure and deteriorating service delivery play a big part in the way people at Lake Kopiago are experiencing HIV and AIDS. Service delivery failure in the health sector means that local aid posts have closed and the Sub-District Health Centre is without lighting, refrigeration, running water or basic medicines. Since 1997 there have been no health or immunisation patrols and disease surveillance has ceased. Sexually transmitted infections now go unchecked and untreated, increasing the likelihood of HIV transmission. Service delivery failure in the education and law and justice sectors is equally critical. School closures and the stalled implementation of elementary schools are behind falling literacy rates and formal education is at risk of disappearing, while police or magisterial services in the Sub-District no longer operate. Consequently witchcraft allegations are being dealt with locally and without reference to the police or courts. Increasingly they are being dealt with violently.

At Kopiago, as this chapter has argued, the HIV epidemic has contributed to the rise of witch-hunts and trials by torture. This has come about because of the culturally specific cosmological understandings Duna have of illness and disease; because AIDS produces the very kinds of deaths that attract witchcraft accusations; and because the illness and death associated with HIV add to a generalised anxiety about witchcraft. Interventions need to be carefully thought through and must take account of the cultural beliefs which inform people's experiences of HIV, for more awareness alone will not necessarily stop the accusations and killings. On the contrary, torture and killing may increase as part of new moralising projects, particularly if these projects accentuate existing beliefs about the potential of any women, who are perceived as insubordinate or transgressive, to do harm. Certainly there is evidence from Kopiago to suggest that recent awareness exercises, depicting women as agents of transmission, have focused much attention on the sexual practices of young women and cast them as predatory, leading to calls that they be 'punished' for their sexual misadventures (cf, MacPherson 2008). Thus PNG's HIV epidemic unfolds not merely as a public health issue of huge proportions, but also threatens to further impact upon law and order. Writing specifically about South Africa, Ashforth (2002, 136) observed that there are 'political implications for the state' when AIDS deaths are 'widely interpreted in terms of witchcraft'. He further cautions that democracy, the legitimacy of the state and the rule of law are threatened by the failure of government authorities to address the issue of witchcraft and 
Civic Insecurity

witchcraft-related violence. Democracy in PNG, which has been described as disorderly, weak and in crisis (May et al. 2003) can scant afford such additional threats.

\section{References}

Anon. 2003a. Minister Horrified. Post-Courier, 19 June 2003.

Anon. 2003b. Deaths from Withcraft, Sorcery a Big Problem. Post-Courier, 29 August 2003.

Anon. 2004a. Seven Tortured. Post-Courier, 6-8 February 2004.

Anon. 2004b. Suspected Sorcerer Tortured and Killed. The National, 10 February 2004.

Anon. 2004c. Getting Away with Murder Every Week. The National, 16 February 2004.

Anon. 2004d. Belief in Witchcraft Causing Bloodshed: Inguba. The National, 8 March 2004.

Anon. 2004e. Two Killed in Sorcery-Related Violence. The National, 9 August 2004.

Anon. 2006. HIV/AIDS Prevalence Rate could be Higher. Post-Courier, 26 September 2006.

Anon. 2007. Witches Tortured over AIDS Deaths in PNG. The National, 27 August 2007.

Anon. 2008. PNG Police Recover Bodies of Women Killed after being Accused of Sorcery. Radio New Zealand International, 24 January 2007.

Anon. 2009. Battle for Sorcery Killings. Post-Courier, 7 April 2009.

Ashforth, A. 2002. An Epidemic of Witchcraft? The Implications of AIDS for the Post-Apartheid State. African Studies 61 (1):121-143.

Ballard, C. 1998. The Sun By Night: Huli Moral Topography of Myths of a Time of Darkness. In Fluid Ontologies: Myth, Ritual and Philosophy in the Highlands of Papua New Guinea, ed. L. R. Goldman and C. Ballard, 67-85. Westport: Bergin and Garvey.

Ballard, C. 2000. The Fire Next Time: The Conversion of the Huli Apocalypse. Ethnohistory 47 (1): 205-225. 
Dokop, M. K. 2004. Research on Sanguma. Post-Courier, 23 February 2004.

Durkheim, E. 1952. Suicide: A Study in sociology. London: Routledge and Paul.

Englund, H. and J. Leach. 2000. Ethnography and the Meta-Narratives of Modernity. Current Anthropology 41 (2): 225-248.

Evans-Pritchard, E. E. 1937. Witchcraft, Oracles and Magic among the Azande. Oxford: Clarendon Press.

Eves, R. 2003. AIDS and Apocalypticism: Interpretations of the Epidemic from Papua New Guinea. Culture, Health and Sexuality 5 (3): 249-264.

Farmer, P. 1990. Sending Sickness: Sorcery, Politics and Changing Concepts of AIDS in Rural Haiti. Medical Anthropology Quarterly 4: 627.

Farmer, P. 1992. AIDS and Accusation: Haiti and the Geography of Blame. Berkeley: University of California Press.

Gerawa, M. and A. Rheeney. 2004. Sir Peter urges MPs to fight HIV. The PostCourier, 13 May 2004.

Glasse, R. 1965. The Huli of the Southern Highlands. In Gods Ghosts and Men in Melanesia, ed. P. Lawrence and M. Meggitt, 27-49. London: Oxford University Press.

Haley, N. C. 2002. Ipakana Yakaiya: Mapping Landscapes, Mapping LivesContemporary Land Politics among the Duna. PhD thesis. Canberra: The Australian National University.

Haley, N. C. 2005. PNG Armed Violence Assessment. In Small Arms Survey. Final report for the United Nations Development Program. October/November 2005. Geneva: UNDP.

Haley, N. C. 2008a. Sung Adornment: Changing Masculinities at Lake Kopiago, Papua New Guinea. In Changing Pacific Masculinities, ed. J. P. Taylor, special issue 20, The Australian Journal of Anthropology 19 (2): 213-229.

Haley, N. C. 2008b. When There's No Accessing Basic Health Care: Local Politics and Responses to HIV/AIDS at Lake Kopiago, Papua New Guinea. In Making Sense of AIDS: Culture Sexuality and Power in Melanesia, ed. L. Butt and R. Eves, 24-40. Honolulu: University of Hawai'i Press.

Haley, N. C. and R. J. May. 2007. Introduction: Roots of Conflict in the Southern Highlands. In Conflict and Resource Development in the Southern Highlands of Papua New Guinea, ed. N. C. Haley and R. J. May, 1-19. Canberra: ANU E Press. 
Haley, N. C. and R. Muggah. 2006. Jumping the Gun: Armed Violence in Papua New Guinea. In Small Arms Survey 2006: Unfinished Business, 165-187. Oxford: Oxford University Press.

Hanson, L. W., B. J. Allen, R. M. Bourke, and T. J. McCarthy. 2001. Papua New Guinea: Rural Development Handbook. Canberra: The Australian National University.

Kelly, R. 1977. Etoro Social Structure: a study in structural contradiction. Ann Arbor: University of Michigan Press.

Knauft, B. 1985. Good Company and Violence: Sorcery and Social Action in a Lowland New Guinea Society. Berkeley: University of California Press.

Kubu, T., Brother Andrew and P. Siba. 2004. Final Report into the Study of Sanguma in the Eastern Highlands and Simbu Provinces. Goroka: Goroka General Hospital.

Lindenbaum, S. 1979. Kuru Sorcery: Disease and Danger in the New Guinea Highlands. California: Mayfield Publishing Company.

Lindenbaum, S. 1981. Images of the Sorcerer in Papua New Guinea. Social Analysis 8:119-128.

May, R. J. ed. 2003. 'Arc of Instability'? Melanesia in the Early 2000s. Canberra: State, Society and Governance in Melanesia Project, The Australian National University; and Christchurch: MacMillan Brown Centre, University of Christchurch.

Maracek, T. 1979. The Death of Koliam: A Witchcraft Killing in a Changing Environment. Oceania 49 (3): 221-225.

Marwick, M. 1965. Sorcery in Its Social Setting: A Study of the Northern Rhodesia Cewa. Manchester: Manchester University Press.

McKay, K, K. Lepani and T. Wagner. 1999. Papua New Guinea Human Development Report 1998. Office of National Planning: Port Moresby.

Muri, David. 2009. Hagen Girl Tied, Burnt to Death. Post-Courier, 7 January 2009.

Poole, F. 1981. Tamam: Ideological and Sociological Configurations of 'Witchcraft' among Bimin-Kuskusmin. Social Analysis 8: 58-76.

Reay, M. 1987. The Magico-Religious Foundations of New Guinea Highlands Warfare. In Sorcerer and Witch in Melanesia, ed. Michele Stephen, 83-120. Carlton: Melbourne University Press. 
Reibe, Inge. 1987. Kalam Witchcraft: A Historical Perspective. In Sorcerer and Witch in Melanesia, ed. Michele Stephen, 211-245. Carlton: Melbourne University Press.

Stadler, J. 2003. Rumor, Gossip and Blame: Implications for HIV/AIDS prevention in the South African Lowveld. AIDS Education and Prevention 15 (4): 357-368.

Steadman, L. 1971. Neighbours and Killers: Residence and Dominance among the Hewa of New Guinea. PhD thesis. Canberra: The Australian National University.

Stephen, M. ed. 1987. Sorcerer and Witch in Melanesia. Carlton: Melbourne University Press.

Stürzenhofecker, G. 1998. Times Enmeshed: Gender, Space, and History among the Duna of Papua New Guinea. Stanford, California: Stanford University Press.

Wagner, R. 1972. Habu: The Innovation of Meaning in Daribi Religion. Chicago: University of Chicago Press.

Wardlow, Holly. 2008. 'You Have to Understand: Some of Us are Glad AIDS has Arrived': Christianity and Condoms among the Huli, Papua New Guinea. In Making Sense of AIDS: Culture, Sexuality, and Power in Melanesia, ed. Leslie Butt and Richard Eves, 187-205. Honolulu: University of Hawai'i Press.

Yamba, C. B. 1997. Cosmologies in Turmoil: Witchfinding and AIDS in Chiawa, Zambia. Africa 67 (2): 200-223.

Zelenietz, M. and S. Lindenbaum, eds. 1981. Sorcery and Social Change in Melanesia. Special Issue Social Analysis 8.

Zocca, Franco (ed.). 2009. Sanguma in Paradise: Sorcery, Witchcraft and Christianity in Papua New Guinea. Point Series No. 33. Goroka: The Melanesian Institute. 